\title{
New soybean (Glycine max Fabales, Fabaceae) sources of qualitative genetic resistance to Asian soybean rust caused by Phakopsora pachyrhizi (Uredinales, Phakopsoraceae)
}

\author{
Pedro Henrique Braga Pierozzi ${ }^{1}$, Aliny Simony Ribeiro ${ }^{2}$, José Ubirajara Vieira Moreira ${ }^{2}$, \\ Larissa DI Cássia Laperuta ${ }^{1}$, Breno Francovig Rachid ${ }^{1}$, Wilmar Ferreira Lima ${ }^{3}$, \\ Carlos Alberto Arrabal Arias ${ }^{2}$, Marcelo Fernandes de Oliveira ${ }^{2}$ and José Francisco Ferraz de Toledo ${ }^{2}$ \\ ${ }^{1}$ Departamento de Biologia Geral, Centro de Ciências Biológicas, Universidade Estadual de Londrina, \\ Londrina, PR, Brazil. \\ ${ }^{2}$ Empresa Brasileira de Pesquisa Agropecuária, Centro Nacional de Pesquisa de Soja, Londrina, PR, Brazil. \\ ${ }^{3}$ Departamento de Agronomia, Centro de Ciências Biológicas, Universidade Estadual de Londrina, \\ Londrina, PR, Brazil.
}

\begin{abstract}
Asian soybean rust (ASR), caused by the phytopathogenic fungi Phakopsora pachyrhizi, has caused large reductions in soybean (Glycine max) yield in most locations in Brazil where it has occurred since it was first reported in May 2001. Primary efforts to combat the disease involve the development of resistant cultivars, and four dominant major genes (Rpp1, Rpp2, Rpp3 and Rpp4) controlling resistance to ASR have been reported in the literature. To develop new long-lasting soybean ASR resistance genes, we used field experiments to assess ASR leaf lesion type in 11 soybean genotypes (BR01-18437, BRS 184, BRS 231, BRS 232, BRSGO Chapadões, DM 339, Embrapa 48, PI 200487, PI 230970, PI 459025-A and PI 200526) and the $55 \mathrm{~F}_{2}$ generations derived from their biparental diallel crosses. The results indicated that PI 200487 and PI 200526 carry different dominant resistance major genes which are both different from Rpp2 through Rpp4. Furthermore, resistance to ASR in BR01-18437 is controlled by a single recessive major gene, also different from Rpp1 through Rpp4 and different from the genes in PI 200487 and PI 200526.
\end{abstract}

Key words: disease resistance, genetic inheritance, major genes, Phakopsora pachyrhizi.

Received: June 22, 2007; Accepted: September 18, 2007.

\section{Introduction}

Asian soybean rust (ASR), caused by the phytopathogenic fungus Phakopsora pachyrhizi, has resulted in considerable yield losses since its detection in Brazil and has provoked great concern to both researchers and farmers. This disease was confirmed on the American continent in Paraguay on March $5^{\text {th }} 2001$ and on May $26^{\text {th }}$ of the same year was detected in the Brazilian state of Paraná from the towns of Foz do Iguassu to Guaíra in the western region and the city of Londrina (Yorinori et al., 2005), spreading to all the main Brazilian soybean (Glycine max) cropping regions over the next two growing seasons.

Considered one of the most devastating of the soybean leaf diseases, ASR causes major economic losses in

Send correspondence to José Francisco Ferraz de Toledo. Empresa Brasileira de Pesquisa Agropecuária, Centro Nacional de Pesquisa de Soja, Rodovia Carlos João Strass, Acesso Orlando Amaral, Caixa Postal 231, 86001-970 Londrina, PR, Brazil. E-mail: toledo@cnpso.embrapa.br. practically all the locations where it is present. The damage is caused by rapid deterioration of the leaf tissue, which makes the leaves dry and fall prematurely thus precluding full grain formation. The earlier the leaves fall, the smaller will be the grain size and, consequently, the greater the loss in yield and quality (Yang et al., 1991). Sinclair and Hartman (1999) reported that the disease caused from $10 \%$ to $40 \%$ damage in Thailand, $10 \%$ to $90 \%$ in India, $10 \%$ to $50 \%$ in southern China, $23 \%$ to $90 \%$ in Taiwan and $40 \%$ in Japan. In Australia, losses of from $60 \%$ to $70 \%$ were reported in the field and $90 \%$ in the greenhouse (Ogle et al., 1979).

Spraying fungicides is the strategy available today to control ASR, but it is costly. The availability of resistant cultivars is the most desirable solution, because its adoption by farmers is simple, cheap and better for the environment. Four dominant major soybean genes controlling resistance to ASR have been identified (Rpp1, Rpp2, Rpp3 and Rpp4), these genes being located at different loci and provide resis- 
tance to different races of P. pachyrhizi. Rppl was identified in soybean genotype PI 200492 (McLean and Byth 1980), Rpp2 in PI 230970 (Bromfield and Hartwig, 1980), Rpp3 in PI 462312 (Hartwig and Bromfield 1983) and Rpp4 in PI 459025 (Hartwig 1986).

The development of soybean cultivars resistant to ASR may prove complicated because monogenic resistance is unlikely to provide lasting protection due to the high genetic variability of $P$. pachyrhizi, several races of which have already been identified (Yamaoka et al., 2002; Miles et al., 2006). Some soybean genotypes initially identified as resistant to ASR have had this resistance broken, as has occurred with the genotypes carrying Rpp 1 and Rpp3 when exposed to the $P$. pachyrhizi Taiwan-72-1 isolate (Hartwig, 1986) and to the new P. pachyrhizi isolate from the Brazilian state of Mato Grosso (MT, the Brazilian government abbreviation for this state), the P. pachyrhizi MT state isolate, described by Yorinori et al. (2004). Soybean resistance provided by $R p p 1$ and $R p p 3$ was defeated by the P. pachyrhizi MT isolate just two years after ASR was first detected in Brazil.

The objective of the study described in this paper was to identify of new sources of resistance to $P$. pachyrhizi because such sources are essential for the development of soybean cultivars resistant to ASR.

\section{Materials and Methods}

\section{Parent soybean plants and segregating generations}

The 11 soybean (Glycine max L. Merrill) parental genotypes selected for study were one advanced breeding line (BR01-18437), six Brazilian commercial cultivars (BRS 184, BRS 231, BRS 232, BRSGO Chapadões, DM 339 and Embrapa 48) and four accessions from the Brazilian National Soybean Research Center 'Embrapa Soybean' (a unit of the Brazilian Agricultural Corporation Empresa Brasileira de Pesquisa Agropecuária - Embrapa) Germplasm Bank (PI 200487, PI 230970, PI 459025-A and PI 200526), which had previously been identified as sources of ASR resistance genes. The letters PI are used to represent plant introductions, which is a designation originally used in the USA to identify plant genetic materials collected all over the world to be kept in the USDA Germplasm Bank. Single plant selections from each of the genotypes were used in the experiment. A diallel cross, without reciprocals, between all the parents was carried out in a greenhouse to obtain 55 biparental combinations in the 2004/05 season (October to April). During the winter of 2005 (May to October) the seeds of the $F_{1}$ generations were sown in the greenhouse to obtain the respective $F_{2}$ generation seeds by selfing. Seeds of all 11 parents were also sown to obtain same-age seeds for a field experiment carried out during the 2005/06 season (November to April). All seeds came from the collection kept for genetic studies and breeding at Embrapa Soybean.

\section{Experimental design and procedures}

The experiment was installed in a field $\left(23^{\circ} 11^{\prime} 34^{\prime \prime} \mathrm{S}\right.$, $51^{\circ} 10^{\prime} 40^{\prime \prime} \mathrm{W}$, altitude $599 \mathrm{~m}$ ) at the Embrapa Soybean experimental field near the city of Londrina in the Brazilian state of Paraná.

The experiment was sown on Nov 10, 2005 in a completely randomized design with single plant hill-plots. We sowed 50 plants for each parent and 120 plants for each $\mathrm{F}_{2}$ generation, resulting in 7,150 hill-plots. To avoid plant stand failure each hill-plot was sown with three seeds of the respective genotype and shortly after emergence the plantlets were randomly thinned to one plant per plot.

The distance between hill-plots within the useful experimental rows was $20 \mathrm{~cm}$, and the distance between the useful rows was $1.5 \mathrm{~m}$. In the interval between two useful experimental rows, two border rows of a mixture of seeds left over from the genotypes under trial were sown, resulting in $0.5 \mathrm{~m}$ spacing between the experiment rows. The sowing densities in the borders were adjusted to bring the experiment plant population close to that of a commercial soybean crop $\left(250,000\right.$ plants $\left.\mathrm{ha}^{-1}\right)$. The soil was an Red Latosol (oxisol) and the experiment received all recommended agricultural practices to ensure normal soybean plant development, including liming, fertilizer application, manual weeding and irrigation.

\section{Inoculum preparation, spraying, assessment and statistical analysis}

Plants of the soybean (Glycine max L. Merrill) BRSMS Bacuri cultivar were grown in $4.0 \mathrm{~kg}$ pots containing a sterilized mixture of soil, sand and manure for approximately 70 days under greenhouse conditions at an average temperature of $25^{\circ} \mathrm{C}$ and natural lighting conditions. At the V3 development stage (Fehr et al., 1971) the plants were inoculated with the Phakopsora pachyrhizi Syd. \& P. Syd 1914 MT state spores. Sowing was planned to allow timely spore collection for inoculating the field experiment when most plants were at the V2 or V3 developmental stage. The BRSMS Bacuri cultivar is resistant to the P. pachyrhizi Southern Brazil isolate (Yorinori, personal communication) and was used as a filter cultivar to ensure predominance of the P. pachyrhizi MT state isolate in the inoculum used to infect the field-grown plants. The Phakopsora pachyrhizi Syd. \& P. Syd 1914 MT state original spores were collected in the State of Mato Grosso by Dr. Tadashi Yorinori in 2002 and kept in the Embrapa Soybean plant pathology collection under freeze-dried stored conditions.

The border rows of the field experiment were inoculated to simulate the natural progress of disease infection to the useful plot area, with uredospores being transferred by the wind to the experimental rows. Two spray inoculations were performed on the experimental border rows with a suspension containing $1 \times 10^{4} \mathrm{~mL}^{-1}$ uredospores in sterilized distilled water supplemented with plus $0.5 \mathrm{~mL}$ of Tween 20. Both inoculations were carried out in late after- 
noon or early evening to avoid the rapid drying of leaf moisture and the deleterious effects of sunshine on $P$. pachyrhizi uredospore germination. The first inoculation was made on the November 30, 2005 when all plants had reached the V2 or V3 development stage (Fehr et al., 1971) and the second on the December 6, 2005 when most plants had reached the V4 development stage. Two supplementary irrigations were applied each week to provide optimum conditions for the ASR development. Details of the inoculation procedures were given in Ribeiro et al. (2007).

The plants in the experiments were assessed for the type of lesion they presented and classified as reddishbrown (RB, the resistance lesion) or light-brown or tan (TAN, the susceptibility lesion), the characteristics of each type of lesion being described by Bromfield et al. (1980). Three assessments were made in the mid-third region of the plants at approximately seven day intervals. The evaluations took place in January 2006, the first on the $11^{\text {th }}$ and $12^{\text {th }}$, the second on the $18^{\text {th }}$ and the third on the $25^{\text {th }}$. The experiment was monitored three times a week to ensure a prompt response to problems that could result in the unreliability of the data collected.

The chi-square $\left(\chi^{2}\right)$ test was used to analyze the data taking into consideration the segregation pattern of the RB and TAN reactions on the leaves of the $F_{2}$ plants of each cross. The 3:1, 9:7, 13:3, 15:1 and 63:1 ratios corresponding to a single, two or three gene segregation were tested for all crosses in each of the three assessments.

\section{Results and Discussions}

All commercial cultivars showed TAN lesions, expressing susceptibility to ASR. The BR01-18437 breeding line and the plant introductions (PIs) expressed the RB lesion type and were defined as carriers of major resistance genes. Some individual plants within each parental genotype displayed different reaction from the predominant resistance or susceptible type (Table 1). Since the parents were homozygous and homogenous lines or cultivars, these discrepancies were most likely due to occasional difficulties in defining the lesion type under field conditions and to variation in the appearance of the lesions with plant age (Ribeiro et al., 2007).

The segregation patterns fitted to the $\mathrm{F}_{2}$ generation at the 5\% probability level of each cross are shown in Table 2. In most cases the genes expressing the RB resistance reaction were dominant over those expressing susceptibility but in a few cases, however, no segregation ratio fitted the expected proportions and, in crosses involving the BR0118437 line, the tested hypothesis was that resistance was controlled by a single recessive gene. The fitted proportion was $1 \mathrm{RB}: 3 \mathrm{TAN}$.

The type of lesion of the parental generation (Table 1) was used to assess the type of cross carried out: resistant (RB) $x$ resistant $(R B)$, resistant $(R B) x$ susceptible (TAN), susceptible (TAN) $x$ resistant (RB) or susceptible (TAN) $\mathrm{x}$ susceptible (TAN). The results of the susceptible (TAN) $x$ susceptible (TAN) crosses that were carried out to investigate soybean quantitative resistance to ASR are not shown in this paper.

Our results confirmed the reports in the literature that PI 230970, carrying the Rpp 2 resistance gene (Hartwig and Bromfield, 1983), and PI 459025-A, carrying the Rpp4 resistance gene (Hartwig, 1986), carry resistance genes at different loci. In the $\mathrm{F}_{2}$ generation of the PI $230970 \mathrm{x}$ PI 459025-A cross the segregation ratios of these two genes were 13:3 for the first assessment, 15:1 for the second and 13:3 for the third (Table 2), showing that these genes segregated independently.

Table 1 - Asian soybean rust individual plant reaction assessments for the parent plants used to produce $\mathrm{F}_{2}$ crosses. The table shows the type of lesion reaction $(\mathrm{RB}=$ resistant, $\mathrm{TAN}=$ susceptible) observed during three assessments and the predominant lesion type (conclusive reaction).

\begin{tabular}{|c|c|c|c|c|c|c|c|}
\hline \multirow{3}{*}{$\begin{array}{l}\text { Parent } \\
\text { plants }\end{array}$} & \multicolumn{6}{|c|}{ Lesion type and frequency } & \multirow{3}{*}{$\begin{array}{l}\text { Conclusive } \\
\text { reaction }\end{array}$} \\
\hline & \multicolumn{2}{|c|}{$1^{\text {st }}$ assessment } & \multicolumn{2}{|c|}{$2^{\text {nd }}$ assessment } & \multicolumn{2}{|c|}{$3^{\text {rd }}$ assessment } & \\
\hline & $\mathrm{RB}$ & TAN & $\mathrm{RB}$ & TAN & $\mathrm{RB}$ & TAN & \\
\hline BR01-18437 & 46 & 4 & 47 & 1 & 49 & 1 & $\mathrm{RB}$ \\
\hline PI 200487 & 46 & 4 & 47 & 2 & 45 & 4 & $\mathrm{RB}$ \\
\hline PI 230970 & 47 & 1 & 45 & 1 & 47 & 1 & $\mathrm{RB}$ \\
\hline PI 459025-A & 49 & 1 & 44 & 2 & 48 & - & $\mathrm{RB}$ \\
\hline PI 200526 & 46 & 2 & 44 & - & 42 & 2 & $\mathrm{RB}$ \\
\hline BRS 184 & 2 & 46 & 7 & 41 & 11 & 37 & TAN \\
\hline BRS 231 & 3 & 46 & 21 & 28 & 18 & 31 & TAN \\
\hline BRS 232 & 3 & 47 & 7 & 41 & 10 & 40 & TAN \\
\hline BRSGO Chapadões & 4 & 45 & 11 & 36 & 8 & 41 & TAN \\
\hline DM 339 & 2 & 48 & 21 & 26 & 15 & 34 & TAN \\
\hline Embrapa 48 & - & 50 & 9 & 39 & 18 & 32 & TAN \\
\hline
\end{tabular}




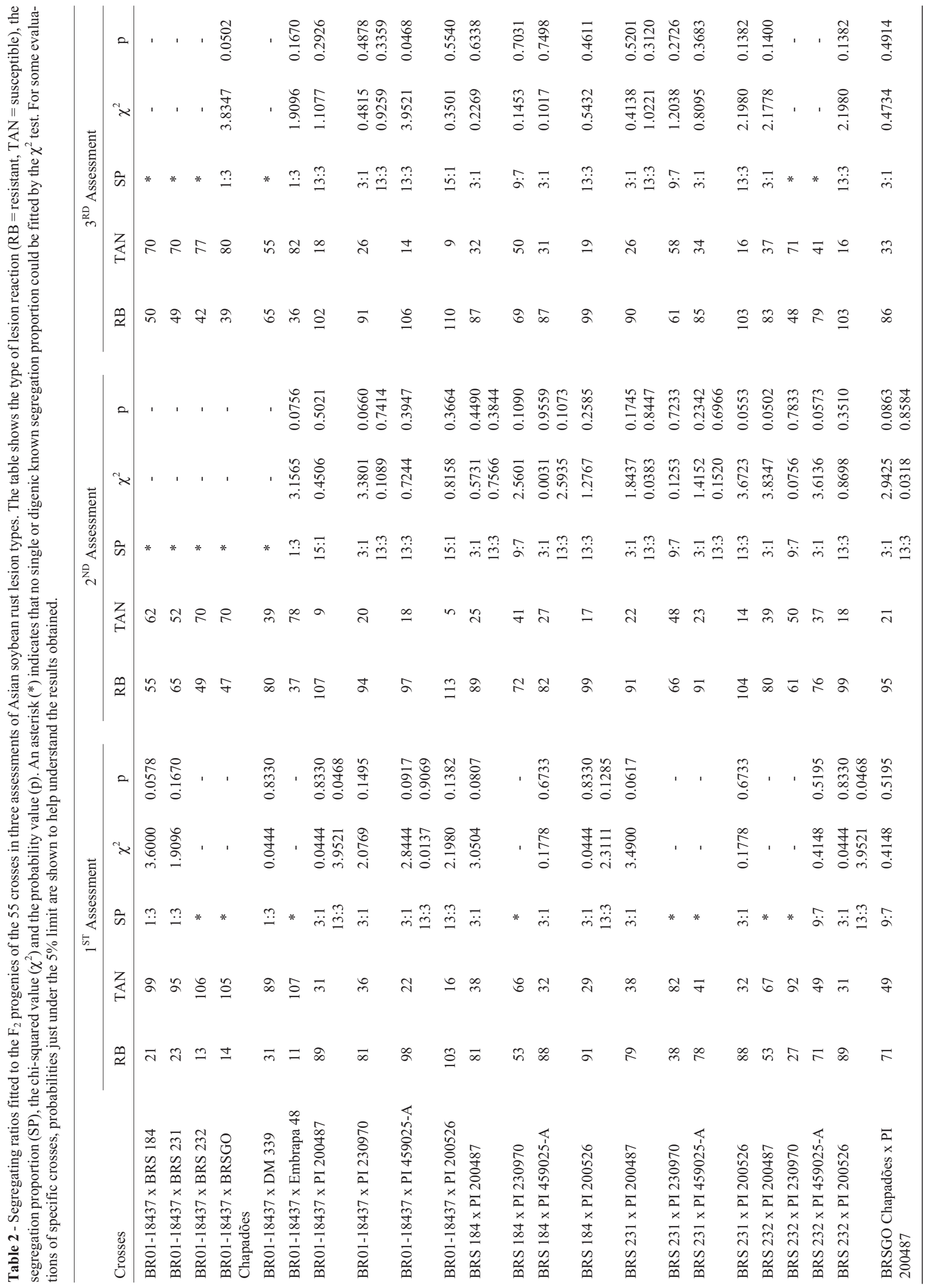




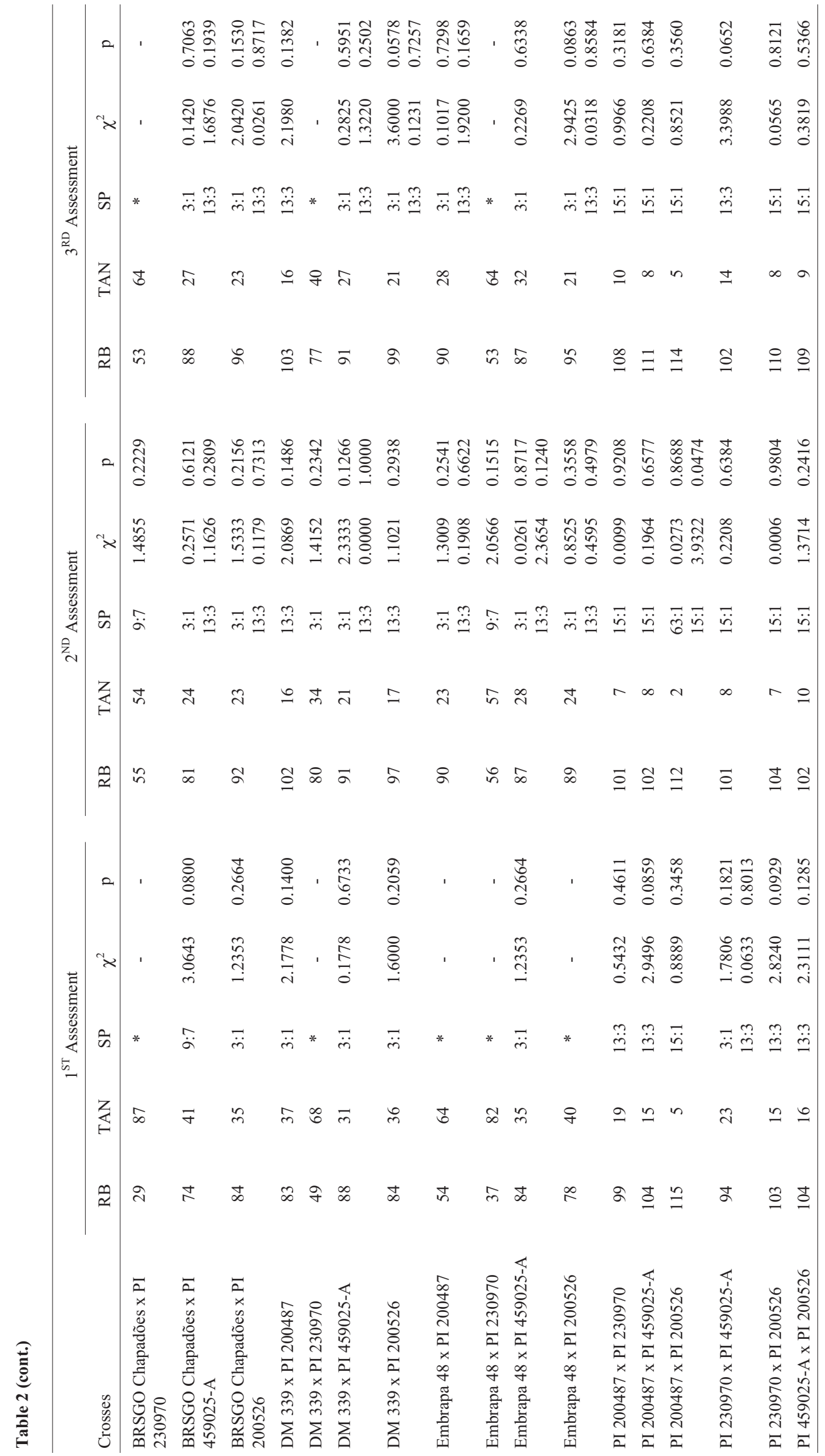


The F2 progeny results of the PI 200487 x PI 230970 , PI 200487 x PI 459025 -A, PI 230970 x PI 200526 and PI 459025-A x PI 200526 crosses showed that for all crosses their resistance genes segregated independently, displaying the observed segregation ratios of 13:3 in the first assessment, 15:1 in the second and 15:1 in the third (Table 2). Therefore, PI 200487 and PI 200526 are carriers of resistance genes located at a locus (or loci) different from Rpp2 and Rpp4. Cross PI 200487 x PI 200526 showed a segregation ratio 15:1 in the first and third assessments and close to 15:1 ratio at the second assessment (Table 2), indicating that their genes segregated independently. The 15:1 segregation ratios indicates the presence of two resistance genes segregating independently, while the 13:3 segregation ratio suggests the presence of digenic epistasis, that is, in the absence of the dominant allele $(\operatorname{Rpp} X)$ of some resistance genes, two dominant alleles of the other gene are needed (RppZRppZ) for the genotype to express the $\mathrm{RB}$ reaction.

In the crosses between PI 459025-A (Rpp4) with BRS 184, BRS 231, BRS 232, BRSGO Chapadões, DM 339 and Embrapa 48, a single resistance gene was detected since a 3:1 segregation ratio prevailed (Table 2). The segregation ratio results from the $\mathrm{F}_{2}$ progeny of the crosses BRS $184 \mathrm{x}$ PI 230970 (Rpp2), BRS 231 x PI 230970, BRS 232 x PI 230970, BRSGO Chapadões x PI 230970 and Embrapa 48 x PI 230970 were always 9:7 (Table 2). This was surprising because these are typical susceptible $\mathrm{x}$ resistant crosses where a 3:1 ratio would be expected. However, since the 9:7 segregation ratio occurred for all crosses it can be inferred that digenic interaction occurred, which leads to the assumption that Rpp2 from PI 230970 interacted with another gene (or genes) from the genetic background of the susceptible cultivars. The 9:7 ratio obtained suggests that $R p p 2_{-}$interacted with an unknown $Y_{-}$gene from the genetic background of the susceptible genotypes used in the crosses. Our hypothesis is that the $7 / 16$ susceptible genotypes in the cross resulted from the fact that the rpp2rpp $2 Y_{-}$ and rpp2rpp2yy plants do not show resistance and that in the Rpp2_yy plants the presence of the double recessive $y y$ genotype inhibited the expression of resistance due to Rpp2. This type of epistasis was narrowly rejected in the third assessment of the DM 339 x PI 230970 cross, while in the first assessment a single gene 3:1 ratio was fitted and in the second assessment no known segregation ratio was fitted (Table 2).

The analyses of the $\mathrm{F}_{2}$ progenies from crosses between PI 200487 with BRS 184, BRS 231, BRS 232, BRSGO Chapadões, DM 339 and Embrapa 48 suggested the expression of a single dominant gene, since the $3: 1$ ratio prevailed (Table 2 ). The only exception was for the $\mathrm{F}_{2}$ progeny from the DM 339 x PI 200487 cross, where a 3:1 segregation ratio was accepted in the first assessment and a 13:3 segregation ratio in the second and third assessments (Table 2). This could be explained by changes in gene expression with plant age as reported by Ribeiro et al. (2007). The analyses of the crosses of the same genotypes with PI 200526 showed that segregation of the $F_{2}$ progenies followed the 13:3 ratio on most occasions and that the 3:1 ratio could not be rejected in a few cases. This suggested the presence of two interacting genes controlling resistance to ASR (Table 2).

The crosses between the BR01-18437 breeding line with each of the five PIs confirmed that it carries a major resistance gene. This gene is at a different locus to Rpp2, based on the 13:3 segregation ratio in the second and third assessments of the cross with PI 230970, or Rpp4, based on the 13:3 segregation ratio in the first and second assessments and close to the 13:3 ratio at the third assessment of the cross with PI 459025-A. The newly discovered gene is also at a different locus to the gene in PI 200487, as based on the close to 13:3 segregation ratio at the first assessment and the $15: 1$ ratio at the second and 13:3 ratio at the third assessment, and to the gene in PI 200526, based on the 13:3 ratio at the first assessment and the 15:1 at the second and third assessments (Table 2).

It is interesting to note that when BR01-18437 was crossed with the BRS 184, BRS 231, BRSGO Chapadões, DM 339 and Embrapa 48 susceptible cultivars the only acceptable segregation ratio in their $F_{2}$ progenies was one resistant to three susceptible genotypes. This suggested BR01-18437 carries a new recessive major gene for resistance to ASR. No known segregation ratio could be fitted to the $F_{2}$ progeny from the cross between BR01-18437 and BRS232 (Table 2). The observed segregations in the $F_{2}$ progenies from the cross between BR01-18437 and the other PIs carrying resistance genes is in agreement with the segregation of two genes, one with a dominant allele interaction and another with a recessive allele interaction. In this case, having RppZ as BR01-18437 gene resistance, the genotypes rppXrppXRppZRppZ and rppXrppXRppZrppZ will result in susceptible plants.

Our results indicated that PI 200487 and PI 200526 carry different dominant resistance major genes which are both different from Rpp2 and Rpp4. The results also suggest that genetic resistance to ASR in the BR01-18437 breeding line is controlled by a single recessive major gene, different from Rpp1 through Rpp 4 and different from the genes of PI 200487 and PI 200526.

\section{Acknowledgments}

The authors thank Embrapa Soybean, and the Brazilian governmental agencies FINEP and the CNPq for financial support. Pedro Henrique Braga Pierozzi, Larissa DI Cássia Laperuta and Breno Francovig Rachid received trainee scholarships from Embrapa Soybean.

\section{References}

Bromfield KR and Hartwig EE (1980) Resistance to soybean rust and mode of inheritance. Crop Sci 20:254-255. 
Bromfield KR, Melching JS and Kingsolver CH (1980) Virulence and aggressiveness of Phakopsora pachyrhizi isolates causing soybean rust. Phytopathology 70:17-21.

Fehr WR, Caviness CE, Burmood DT and Pennington JS (1971) Stage of development descriptions for soybeans, Glycine $\max ($ L.) Merril. Crop Sci 11:929-931.

Hartwig EE (1986) Identification of a fourth major gene conferring resistance to soybean rust. Crop Sci 26:1135-1136.

Hartwig EE and Bromfield KR (1983) Relationships among three genes conferring specific resistance to rust in soybeans. Crop Sci 23:237-239.

McLean RJ and Byth DE (1980) Inheritance of resistance to rust (Phakopsora pachyrhizi) in soybeans. Aust J Agric Res 31:951-956.

Miles MR, Frederick RD and Hartman GL (2006) Evaluation of soybean germplasm for resistance to Phakopsora pachyrhizi. Plant Health Progress, available at http://www. soydiseases.uiuc.edu/index.cfm?category $=$ researchers\& person $=$ mrmiles.

Ogle HJ, Byth DE and McLean RJ (1979) Effect of rust (Phakopsora pachyrhizi) on soybean yield and quality in south-eastern Queensland. Aust J Agric Res 30:883-893.
Ribeiro AS, Moreira JUV, Pierozzi PHB, Rachid BF, Toledo JFF, Arias CAA, Soares RM and Godoy CV (2007) Genetic control of Asian rust in soybean. Euphytica 157:15-25.

Sinclair JB and Hartman GL (1999) Soybean rust. In: Hartman GL, Sinclair JB and Rupe JC (eds) Compendium of Soybean Diseases. 4th ed. American Phytopathological Society Press, St. Paul, pp 25-26.

Yamaoka Y, Fujiwara Y, Kakishima M, Katsuya K, Yamada K and Hagiwara H (2002) Pathogenic races of Phakopsora pachyrhizi on soybean and wild host plants collected in Japan. J Gen Plant Pathol 68:52-56.

Yang XB, Tschanz AT, Dowler WM and Wang TC (1991) Development of yield loss models in relation to reductions of components of soybean infected with Phakopsora pachyrhizi. J Phytopathol 81:1420-1426.

Yorinori JT, Junior JN and Lazzarotto JJ (2004) Ferrugem “asiática" da soja no Brasil: Evolução, importância econômica e controle. Embrapa Soja, Londrina, 36 pp.

Yorinori JT, Paiva WM, Frederick RD, Costamilan LM, Bertagnolli PF, Hartman GE, Godoy, CV and Nunes Jr J (2005) Epidemics of soybean rust (Phakopsora pachyrhizi) in Brazil and Paraguay from 2001 to 2003. Plant Dis 98:675-677.

Senior Editor: Ernesto Paterniani

License information: This is an open-access article distributed under the terms of the Creative Commons Attribution License, which permits unrestricted use, distribution, and reproduction in any medium, provided the original work is properly cited. 